\title{
PENGUATAN LITERASI BUDAYA BAGI PELAKU SENI BUDAYA DESA KALIREJO, KECAMATAN KOKAP, KABUPATEN KULON PROGO
}

\author{
Entoh Tohani \\ email: tohani@uny.ac.id \\ Sugito \\ email: sugito@uny.ac.id
}

Universitas Negeri Yogyakarta

Jl. Colombo No.1, Karang Malang, Caturtunggal, Kec. Depok, Kabupaten Sleman, Daerah Istimewa

Yogyakarta 55281

\begin{abstract}
Abstrak: Penelitian ini bertujuan untuk mengembangkan kemampuan literasi budaya bagi pelaku seni budaya dalam rangka memberdayakan masyarakat. Kemampuan literasi budaya para pelaku seni budaya yang belum optimal berimplikasi pada keberadaan potensi budaya dimana belum termanfaatkan secara optimal untuk mengembangkan budaya masyarakat. Penelitian ini merupakan penelitian tindakan dengan tahapan pengkajian isu, perencanaan, pelaksanaan, dan pengimplementasian tindakan serta refleksi dan perbaikan rencana tindakan. Tindakan dilakukan dalam bentuk pendidikan literasi kepada para pelaku seni-budaya di Desa Kalirejo Kecamatan Kokap Kabupaten Kulon Progo. Pengumpulan data dilakukan dengan wawancara dan observasi. Data dianalisis secara kualitatif yaitu direduksi, disajikan dan ditarik kesimpulan. Teknik analisis data dilakukan dengan pengamatan perpanjangan dan tringulasi. Hasil penelitian menunjukkan bahwa tindakan yang diberikan kepada para pelaku seni-budaya dapat memberikan perubahan positif dimana kelompok sasaran dapat lebih memiliki kesadaran dan pemahaman yang baik mengenai kemampuan literasi budaya untuk memajukan budaya masyarakat. Oleh karenanya, tindakan berkesimbungan dan relevan perlu dilaksanakan kembali di masa depan dengan menyediakan fasilitas yang memadai.
\end{abstract}

Kata-kata kunci: literasi budaya, penguatan, seni budaya

\section{STRENGTHENING CULTURAL LITERACY FOR THE ACTORS OF ARTS AND CULTURE IN KALIREJO VILLAGE, KOKAP DISTRICT, KULON PROGO REGENCY}

\begin{abstract}
This research aims to develop cultural literacy competency of the actor of arts and culture in the context of empowering community. It is urgent to be conducted considering community's limited competency that might implicates to their cultural community potency. This research is an action research which include some steps as follow: issues/problems investigation, action planning, implementation, and reflection. The implementation was conducted in the form of cultural literacy teaching process toward the target group in Kalirejo, Kokap, Kulon Progo Regency. The data was collected by using interview and observation method and analyzed by using qualitative analysis technique which includes data reduction, display, and conclusion. To gain the data validity, triangulation and advance observation were conducted. The research findings showed that the implementation could make positive changes for the targets in which they have competencies such as good consciousness and understanding to promote community's culture. Therefore, sustainable and relevant activities need to be done in the future and by providing an adequate facility.
\end{abstract}




\section{PENDAHULUAN}

Desa Kalirejo merupakan salah satu desa di Kecamatan Kokap, Kabupaten Kulon Progo yang di samping tergolong pada wilayah yang berpotensi bencana alam cukup tinggi berupa tanah longsor, kekeringan, angin kencang, wabah penyakit, dan kecelakaan kerja juga memiliki potensi yang perlu dikembangkan yaitu potensi budaya yang dimiliki dan berkembang di masyarakat (Tohani, Wibawa, \& Djazifah, 2017). Potensi budaya dimaksud berupa terdapat banyak perkumpulan warga masyarakat yang menggeluti kesenian tradisional dan/atau keagamaan misal hadroh, kethoprak, jathilan, karawitan, gejog lesung, sholawatan, dan music dangdut serta beberapa situs sejarah. Perkumpulan dimaksud dipandang sebagai wadah yang memberikan wahana pengembangan diri dan masyarakat yang optimal, sekaligus membudayakan dan mentransmisikan kebudayaan masyarakat (Fagerlind \& Saha, 1983).

Kehadiran kelompok-kelompok seni budaya ini belum memberikan manfaat yang besar terhadap kehidupan masyarakat yang ditandai dengan dua hal. Pertama, kegiatan rutin kelompok yang kurang kreatif, mengandalkan cara lama, pengelolaan masih sederhana, sebatas untuk mengisi waktu luang, dilakukan secara tidak profesional, belum memberikan manfaat ekonomi, dan akhir-akhir ini cenderung kurang diminati dan ditinggalkan oleh generasi muda. Kedua, pengembangan pengelolaan kelompok seni budaya pun sangat minim. Aktivitas pendidikan untuk mengembangkan kualitas kemampuan mengelola organisasi dan/atau aktivitas seni budaya bagi warga masyarakat terutama mereka yang terlibat langsung agar menjadi lebih produktif secara ekonomi dan sosial belum banyak dilakukan baik oleh masyarakat sendiri, pemerintahan desa setempat maupun pihak luar. Ketiga, adanya tantangan perubahan struktural dan kultural masyarakat sebagai akibat adanya pembangunan bandara internasional New Yogyakarta International Airport di wilayah Kecamatan Temon Kabupaten Kulonprogo.

Para pelaku seni budaya yang tergabung dalam kelompok-kelompok kesenian perlu meningkatkan produktivitasnya. Salah satunya adalah kemampuan melek budaya (literasi budaya) perlu dimiliki oleh warga masyarakat di Desa Kalirejo sebagai kemampuan dalam mengatasi permasalahan yang muncul dalam kehidupan bermasyarakat. Literasi budaya (cultural literacy) dimaknai sebagai kemampuan untuk memahami budaya yang dimiliki, mengantisipasi perubahan budaya, melestarikan budaya, mengembangkan budaya, dan/atau menciptakan budaya dalam perwujudannya. Literasi budaya merupakan salah satu dimensi dari literasi ganda yang pada dasarnya tujuan pendidikan literasi berbeda-beda terkait dengan bidang kehidupan (UNESCO, 2006; Sumarno, 2009). Literasi ini bertujuan untuk membentuk warga masyarakat memiliki pemahaman yang baik terhadap warisan, budaya, sejarah, sastra, politik dan lainnya yang dimiliki oleh masyarakat, membangun cultural competency yang merupakan kepemilikan sikap, keterampilan praktik, dan pengetahuan yang cerdas sesuai dengan situasi lintas budaya/heterogen, dan kemampuan merefleksikan secara kritis dan lakukan perubahan dalam budaya sendiri (Hirsch, 1983).

Peningkatan kemampuan literasi budaya menjadi tugas bersama warga masyarakat dan lembaga pendidikan berbasis masyarakat yang memfokuskan pada kegiatan pengembangan budaya seperti kelompok-kelompok seni-budaya. Menurut Kemdikbud (2017) suatu masyarakat yang memiliki kemampuan literasi budaya yang baik ditandai dengan beberapa indikatornya mencakup: terjadi peningkatan pada jumlah dan variasi bahan bacaan literasi budaya yang dimiliki setiap desa, frekuensi membaca bahan bacaan literasi budaya setiap hari, jumlah bahan bacaan literasi budaya yang dibaca oleh masyarakat setiap hari, jumlah partisipasi aktif komunitas, lembaga, atau instansi dalam penyediaan bahan bacaan, jumlah fasilitas publik yang mendukung literasi budaya, jumlah kegiatan literasi budaya yang ada di masyarakat, partisipasi aktif masyarakat dalam kegiatan literasi budaya, jumlah pelatihan literasi budaya yang aplikatif dan berdampak pada masyarakat, jumlah kegiatan budaya di masyarakat, jumlah produk budaya yang dimiliki dan dihasilkan oleh masyarakat, dan penggunaan bahasa daerah di suatu daerah.

Agar perubahan kebudayaan masyarakat tetap mengarah pada tujuan positif, pendidikan memiliki peran strategi dalam rangka mengembangkan budaya suatu masyarakat khusus kompetensi literasi budaya. Menurut Ife (1997) dalam konteks pemberdayaan masyarakat, pendidikan dapat diarahkan untuk mengembangkan budaya masyarakat khususnya untuk melestarikan dan menilai budaya lokal, melestarikan dan menilai budaya asli, mengembangkan budaya multikultural, dan mengembangkan budaya partisipatoris. Pai (1990) memberikan pemahaman lain bahwa pendidikan dapat digunakan untuk melestarikan budaya, merubah tatanan sosial budaya masyarakat 
dan menghapus perilaku bias di masyarakat. Gardner (dalam Suárez-Orozco \& Qin-Hilliard, 2004) merinci bahwa pendidikan terkait dengan globalisasi ekonomi, sosial budaya, dan ilmu pengetahuan teknologi perlu membekali warga masyarakat untuk: memahami sistem global, memiliki kemampuan berfikir analitis dan kreatif, memiliki kemampuan mengkaji masalah, memiliki pengetahuan mengenai budaya dan tradisi masyarakat lain dan berinteraksi dengan nya secara produktif, memiliki pengetahuan dan penghargaan pada tradisinya sendiri, membentuk indentitas hybrid/ perpaduan, dan mampu membentuk toleransi lintas budaya, agama, ras, dll. Maka, dapat dikatakan kemampuan literasi memungkinkan individu dapat beradaptasi dengan perubahan masyarakat yang cepat, globalitasi, pengaruh teknologi informasi dan komunikasi, dan masalah penyebaran penyakit
(Lind, 2008; Gee, 2015) dan sebagai hak manusia dan tanggung jawab individu dan koletif (Keefe \& Copeland, 2011).

Mendasarkan pada pemikiran di atas, penelitian ini dilakukan untuk mengembangkan kemampuan literasi budaya para pelaku seni budaya desa Kalirejo agar mereka mampu memainkan peranan lebih produktif dan inovatif dalam memanfaatkan potensi budaya sebagai salah satu kearifan lokal yang ada di lingkungan sekitar sehingga mampu menjadi produk/jasa yang bernilai ekonomis. Oleh karenanya, dipandang perlu melakukan kegiatan penguatan literasi budaya dalam bentuk kegiatan pendidikan literasi budaya yang didasarkan pada prinsip pemanfaatan potensi lokal.

\section{METODE PENELITIAN}

Penelitian ini menggunakan pendekatan penelitian tindakan (action research) yang dimaksudkan untuk mengembangkan kemampuan literasi budaya bagi para pelaku seni budaya yang ada di Kalirejo. Model penelitian tindakan yang digunakan adalah model penelitian tindakan partisipatoris yang menekankan para kemitraan pada proses pembelajaran atau pengembangan masyarakat. Pelaksanaan kegiatan bersifat siklis/spiral yaitu: mempertanyakan dan menginvestigasi isu spesifik, merencanakan tindakan dan mengimplementasikan tindakan dan merefleksi untuk memperbaiki rencana tindakan (McIntyre, 2007). Dalam penelitian ini, tindakan dilakukan dalam sekali siklus penelitian.

Pengumpulan data dilakukan dengan wawancara dan observasi sesuai dengan pelaksanaan pada masing-masing tahapan penelitian tindakan dimaksud. Wawacara dilakukan kepada kepala desa kepala dusun, kader pemberdayaan masyarakat, ketua kelompok seni-budaya, dan beberapa orang pelaku seni-budaya. Pengumpulan data dilakukan oleh peneliti bekerja sama dengan ketua kelompok seni budaya. Data dianalisis dengan menekankan pada refleksi bersama peneliti dan kelompok sasaran.

Penelitian tindakan ini dilakukan pada Bulan Juli sampai dengan Oktober 2018. Penelitian ini berlokasi di Desa Kalirejo Kecamatan Kokap Kabupaten Kulon Progo sebagai desa yang sedang berusaha menjadi desa budaya. Partisipan penelitian ini sebanyak 30 orang pelaku seni budaya yang terdiri dari terdiri dari 19 perempuan dan 11 laki-laki. Pemilihan kelompok sasaran ini didasarkan pada keaktifan dalam penyelenggaran seni budaya di desa tersebut. Penentuan partisipan penelitian dilakukan secara langsung dengan mempertimbangkan kesediaan, ketersediaan waktu partisipan dan waktu pelaksanaan.

\section{HASIL DAN PEMBAHASAN}

\section{Hasil penelitian}

Hasil penelitian tindakan ini dapat dideskripsikan di bawah ini dengan mengacu pada kerangka kegiatan dalam penelitian tindakan meliputi: analisis isu/masalah, perencanaan tindakan, pelaksanaan tindakan dan refleksi bersama.

\section{Analisis isu/masalah}

Analisis masalah atau isu dilakukan dengan diskusi dengan para pelaku budaya yang dipandang mengetahui budaya dan perkembangan masyarakat. Dalam hal ini, peneliti melakukan diskusi terfokus mendalam dengan beberapa pelaku seni-budaya dan dengan tokoh masyarakat yaitu kepala Desa Kalirejo, dan Dukuh Sengir. Diskusi dengan para pelaku menekankan pada bagaimana perkembangan dan permasalahan yang terkait seni-budaya di Desa Kalirejo. Diketahui bahwa pengelolaan seni budaya Desa Kalirejo belum dilakukan secara optimal yang didukung dengan kemampuan profesional sumber daya manusia yang terlibat di dalamnya. Sebagaimana disampaikan seorang pelaku seni-budaya berisial $\mathrm{Hr}$, yang juga seorang kepala dusun, mengungkapkan bahwa selama ini mereka menghadapi kenyataan 
dalam kehidupan masyarakat yaitu rendahnya minat anak muda untuk melestarikan budaya dan belum ada pihak yang membantu mendampingi kelompok. Begitu pula Kepala Desa Kalirejo memandang bahwa seni-budaya yang ada belum dapat dioptimalkan, banyak kelompok-kelompok seni-budaya yang stagnan perkembangannya karena ketidakmampuan untuk berkreasi terus-menerus. Melalui diskusi tersebut dihasilkan pula suatu pemikiran bagaimana tindakan mengembangkan literasi budaya bagi para pelaku seni budaya yang ada di Kalirejo. Tindakan yang disepakati untuk mengatasi masalah tersebut yaitu upaya meningkatkan produktivitas pengelolaan aktivitas seni-budaya Kalirejo.

\section{Perencanaan}

Perencanaan tindakan dalam penguatan literasi budaya diawali dengan penentuan pembelajaran secara partisipatoris. Perencanaan dilakukan dengan mengikutsertakan para pihak terkait yaitu kelompok sasaran, tokoh masyarakat, dan pemerintah desa. Perencanaan dengan kelompok sasaran untuk menghasilkan kesepakatan bersama mengenai teknis pelaksanaan pembelajaran antara lain waktu pembelajaran, tempat pembelajaran, mekanisme pembelajaran, penetapan narasumber sesuai dengan tema yang disepakati, waktu pelaksanaan, dan teknis akomodasi dan komunikasi dengan kelompok sasaran yang terlibat. Tempat pembelajaran dilakukan di balai dusun Sengir dan teknis akomodasi difasilitasi oleh para ibu-ibu pengurus Dusun Sengir. Rencana pembelajaran disajikan pada tabel 1.

Dalam perencanaan ini pun peneliti berkoordinasi dengan kepala dusun dan kepala Desa Kalirejo untuk memberikan informasi akan tujuan pengembangan dan membuka kesadaran aparatur desa dalam mengoptimalkan potensi alam dan keberadaan kelompok sasaran. Hasil koordinasi dengan pihak pemerintah ini adalah dukungan pemerintah setempat sangat positif terhadap pelaksanaan kegiatan pengembangan kelompok sasaran. Sedangkan perencanaan secara internal terutama pada aspek substansi literasi budaya, tim peneliti melakukan perencanaan pembelajaran sesuai dengan tujuan penguatan literasi budaya berdasarkan kebutuhan yang diperoleh dari hasil diskusi dengan kelompok sasaran.

Tabel 1 Rencana kegiatan penguatan

\begin{tabular}{|c|c|c|c|c|c|}
\hline Tahap & Materi & Tujuan pembelajaran & Pertemuan ke- & Metode & Pelaksana \\
\hline 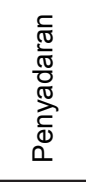 & Penyadaran & $\begin{array}{l}\text { Membangun kesadaran, } \\
\text { dan komitmen kelompok } \\
\text { sasaran akan pentingnya } \\
\text { literasi budaya bagi pelaku } \\
\text { seni budaya sebagai agent } \\
\text { pengembangan budaya }\end{array}$ & $1(1 / 9 / 2018)$ & Brainstorming & $\begin{array}{c}\text { Tim peneliti } \\
\text { Kelompok sasaran }\end{array}$ \\
\hline \multirow[t]{2}{*}{$\begin{array}{l}\text { ஹ } \\
\text { Dू } \\
\text { வ }\end{array}$} & Literasi budaya & $\begin{array}{l}\text { - Memberikan sikap, } \\
\text { pengetahuan dan } \\
\text { keterampilan kepada } \\
\text { kelompok sasaran } \\
\text { mengenai: a) urgensi } \\
\text { literasi budaya dalam } \\
\text { kehidupan masyarakat } \\
\text { dan pembangunan, b) } \\
\text { pemanfaatan potensi } \\
\text { budaya lokal yang memiliki } \\
\text { social-ekonomi bagi } \\
\text { masyarakat, c) peranan } \\
\text { strategi pelaku seni budaya } \\
\text { dalam kelestarian dan } \\
\text { transformasi budaya, d) } \\
\text { pengelolaan seni budaya } \\
\text { yang bermanfaat }\end{array}$ & $2(22 / 9 / 2018)$ & $\begin{array}{l}\text { Ceramah, } \\
\text { Diskusi }\end{array}$ & $\begin{array}{c}\text { Tim peneliti } \\
\text { Nara sumber } \\
\text { Kelompok sasaran }\end{array}$ \\
\hline & Praktik seni-budaya & $\begin{array}{l}\text { Membangun sikap, } \\
\text { pengetahuan dan } \\
\text { keterampilan dalam } \\
\text { mengelola program } \\
\text { senibudaya berbasis } \\
\text { kearifan local melalui } \\
\text { pembelajaran dari best } \\
\text { practice pengelolaan } \\
\text { senibudaya }\end{array}$ & $3(7 / 10 / 20018)$ & $\begin{array}{l}\text { Learning by } \\
\text { experiences }\end{array}$ & $\begin{array}{l}\text { Praktisi sukses } \\
\text { Kelompok sasaran }\end{array}$ \\
\hline 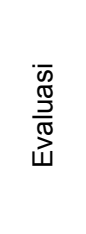 & Evaluasi hasil & $\begin{array}{l}\text { - Mengetahui capaian } \\
\text { perubahan perilaku } \\
\text { kelompok sasaran sebagai } \\
\text { hasil belajar yang diperoleh } \\
\text { Membangun kesepahaman } \\
\text { dan komitmen kelompok } \\
\text { sasaran untuk menerapkan } \\
\text { hasil belajar }\end{array}$ & $3(7 / 10 / 20018)$ & $\begin{array}{l}\text { Pengamatan, } \\
\text { wawancara }\end{array}$ & $\begin{array}{l}\text { Tim pengabdi } \\
\text { Narasumber } \\
\text { Kelompok sasaran }\end{array}$ \\
\hline
\end{tabular}




\section{Pelaksanaan}

Pelaksanaan penguatan literasi budaya dilakukan sesuai dengan waktu yang disepakati dalam bentuk pelatihan yang menekankan pada pengalaman sebagai titik tolak pembelajaran. Proses pembelajaran dibagi dalam empat sesi pembelajaran yaitu: penyadaran, pembelajaran literasi budaya dengan pendekatan pembelajaran berbasis pengalaman oleh narasumber, pembelajaran analisis kasus, dan refleksi bersama. Pertama, penyadaran. Penyadaran dilakukan untuk menjelaskan mengenai urgensi pelestarian budaya yang dimiliki oleh warga masyarakat. Dengan menggunakan bahasa lokal (Jawa) agar komunikasi lebih efektif dan pendekatan yang hangat/dialogis, peneliti memberikan pandangan kepada kelompok sasaran bahwa budaya yang ada di lingkungan masyarakat perlu tetap dilestarikan terutama menghadapi perubahan yang sedang terjadi di wilayah Kulonprogo yaitu pengembangan New Yogyakarta International Airport. Ditegaskan bahwa apabila warga masyarakat tidak dapat melihat dan memanfaatkan peluang dari perubahan ini, maka mereka akan sekedar menonton perubahan yang terjadi bahkan tidak dapat merasakan manfaatnya. Oleh karena itu, penting penguasaan literasi budaya bagi semua warga masyarakat agar mereka dapat beradaptasi dengan perubahan Kulonprogo. Pada kesempatan ini warga belajar nampaknya memiliki pandangan yang sama pentingnya literasi budaya, seperti pendapat seorang pelaku seni ketoprak yang memandang bahwa ia terus berkecimpung dalam pengelolaan seni-budaya walau sudah tua, karena baginya budaya jangan sampai punah.

Kedua, penyampaian materi mengenai makna literasi budaya. Tujuan pembelajaran adalah memberikan pemahaman mengenai pentingnya kapasitas budaya dan literasi budaya dimiliki oleh masyarakat dalam upaya mengembangkan kehidupan masyarakat. Makna dan bentuk budaya, makna dan urgensi literasi budaya, tujuan dan alasan kemunculkan literasi budaya, dan kegiatan pengembangan literasi budaya yang dapat dilakukan oleh masyarakat serta indikator-indikator keberhasilannya. Contoh-contoh nyata yang dapat memberikan gambaran bagaimana kemampuan literasi dapat dimiliki oleh masyarakat dalam rangka memberdayakan masyarakat misalnya gambaran negatif mengenai ketiadaan literasi budaya yang terjadi di suatu masyarakat Sunda dimana adanya mitos yang melarang pementasan wayang golek dapat memusnahkan seni tradisi tersebut. Selain dengan berdiskusi, pembelajaran pun menggunakan media video mengenai pengelolaan seni-tradisi. Kelompok sasaran diminta untuk mengamati penayangan video pengelolaan desa wisata budaya Panglipuran, Kabupaten Bangli, Provinsi Bali. Dalam suasana santai, para warga belajar mengamati apa yang ditampilkan dalam video. Setelah video selesai ditayangkan, peneliti menjelaskan mengenai bagaimana pengelolaan budaya-tradisi pada masyarakat yang dipaparkan dalam video mendasarkan pada pengalaman langsung peneliti misalnya menjelaskan pengembangna komitmen bersama semua lapisan masyarakat dalam mendukung desa budaya, sanksi yang dikenakan pada warga yang melanggar, dan aturan-aturan berinteraksi dengan pihak lain atau sesama warga masyarakat. Selanjutnya, peneliti mengajak kelompok sasaran untuk menyimpulkan pesan apa yang dapat diperoleh dari tayangan video dimaksud. Akhirnya, peneliti memberikan kesimpulan bahwa literasi budaya harus dikuasai oleh semua pelaku seni-budaya karena budaya akan dapat berkembang, stagnan, bahkan mati.

Ketiga, pembelajaran berbasis pengalaman mengenai pengelolaan seni budaya tradisional yang dilakukan narasumber. Narasumber adalah seorang dosen seni musik sekaligus berperan sebagai salah satu anggota pengembangan budaya Kabupaten Sleman. Tujuan pembelajaran ini adalah memberikan pengetahuan dan keterampilan kepada kelompok sasaran mengenai pengelolaan seni budaya tradisional untuk mengembangkan masyarakat. Narasumber memberikan materi terkait dengan bagaimana mengembangkan seni budaya tradisional yang mampu memberikan manfaat kepada masyarakat dengan dasar pengalaman yang dimilikinya. Substansi pendidikan mencakup contoh-contoh sukses (best practice) pengembangan seni budaya pada masyarakat lain, fungsi seni tradisional, dampak seni-budaya dalam pengembangan masyarakat, dan kegiatan-kegiatan pengembangan seni tradisional. Pada kesempatan belajar ini, warga belajar berkomunikasi aktif untuk menanggapi atau menyetujui materi yang diungkapkan narasumber misalnya terdapat warga masyarakat yang mempertanyakan bagaimana mengembangkan aspek pendanaan dan mengapa seni budaya bisa mati. Dilihat dari kehadiran kelompok sasaran, terdapat 5 orang warga belajar yang tidak dapat mengikuti kegiatan pembelajaran ini karena kesibukan bekerja di waktu yang bersamaan.

Tahap terakhir adalah evaluasi. Evaluasi pembelajaran dilakukan untuk melihat kebermaknaan kegiatan pembelajaran yang telah dilakukan. Evaluasi dilakukan dengan mengamati apa yang terjadi selama proses pembelajaran. Peneliti mencatat bagaimana 
perilaku warga belajar, interaksi edukatif yang terjadi dalam penelajaran, suasana yang terjadi selama kegiatan, dan lain-lain.

\section{Refleksi bersama}

Kegiatan refleksi terhadap tindakan penguatan dilakukan secara bersama-sama antara peneliti maupun kelompok sasaran. Refleksi dilakukan dalam bentuk dialog bersama yang diselenggarakan setelah proses pembelajaran. Proses dialog dilakukan dengan terlebih dahulu peneliti menanyakan kepada kelompok sasaran bagaimana tindakan pembelajaran yang telah dilakukan bermakna? Terhadap pertanyaan ini, beberapa orang warga belajar menyampaikan pandangannya secara bergantian mengenai aktivitas pembelajaran yang sudah diikuti. Hasil refleksi bersama mengenai tindakan penguatan yang telah dilakukan menunjukkan bahwa kelompok sasaran menyadari pentingnya literasi budaya dimiliki untuk mengembangkan budayanya agar tetap berkembang, dan memiliki motivasi yang kuat untuk memajukan seni budaya yang ada di lingkungannya. Mereka menyadari budaya yang ada belum dikelola secara optimal dan dilakukan dengan prinsip yang penting berjalan, belum mengarah pada penyelenggaraan seni tradisi yang berorientasi pada proses pengembangan masyarakat yang lebih produktif. Selain itu, mereka pun menyampaikan harapan-harapan di masa depan dalam memajukan kegiatan pengembangan seni budaya baik dalam pengelolaan, penataan gerak, penataan musik, dan sebagainya.

\section{Pembahasan}

Para pelaku seni budaya yang berada di Desa Kalirejo memiliki peranan strategis dalam proses mentransmisikan dan mentransformasikan dimensidimensi budaya dalam kehidupan masyarakat baik dalam satu generasi maupun lintas generasi. Sudah selayaknya, mereka berkemampuan memahami dan mengelola budaya secara sadar dan bermakna. Kemampuan literasi dimaknai sebagai kemampuan individu dalam memahami budaya dan mengembangkan budaya yang dimilikinya sendiri, sekaligus kemampuan untuk memahami dan berinteraksi dengan masyarakat lain yang memiliki budaya yang berbeda. Kemampuan ini perlu dimiliki oleh setiap warga masyarakat agar mampu melestarikan budaya dan beradaptasi dalam lingkungan masyarakat yang heterogen. Oleh karenanya, penguatan literasi budaya bagi para pelaku seni budaya dilakukan untuk membekali para pelaku seni budaya dengan pemahaman dan keterampilan kemampuan literasi yang dapat digunakan unutk mengembangkan budaya yang ada di masyarakat.

Temuan penelitian ini menunjukkan bahwa kelompok sasaran memahami mengenai bagaimana kemampuan literasi budaya dalam mengembangkan seni-budaya lokal harus dibangun dalam upaya memajukan masyarakat agar sejahtera, dan menyadari bahwa pengembangan seni budaya membutuhkan tindakan kreatif dari mereka sendiri dan dengan melakukan pengembangan budaya berbasis para masyarakat. Hal ini menunjukkan bahwa proses pengembangan kelompok sasaran berjalan efektif apabila pembelajaran dapat terkait dengan masalah di masyarakat, mengandung keterlibatan kelompok sasaran, dan bertitik tolak dari kesadaran dan pengalaman individu untuk berubah (Knowless, Holton \& Swanson, 2005; Foley, 2004). Hal ini pun didukung dengan temuan bahwa partisipasi sangat menentukan keberhasilan pembelajaran dalam pendidikan nonformal (Arbrini, dkk., 2018; Muarifuddin, 2017; Widayati, 2006; Hermawan \& Suryono, 2016; Aminah \& Prasetyo, 2018).

Keberhasilan penguatan literasi budaya sangat ditentukan oleh seberapa besar motivasi kelompok sasaran dalam menginternalisasi sikap, pengetahuan, dan keterampilan literasi budaya. Adanya motivasi berarti kesadaran untuk belajar pun akan optimal (Illeris, 2004). Dengan memiliki motivasi tinggi, para pelaku akan memiliki kemampuan dalam belajar yang besar untuk menguasai kemampuan literasi budaya, sebaliknya motivasi yang rendah menyebabkan internalisasi kemampuan ini akan terhambat. Diketahui bahwa dalam proses pembelajaran kelompok sasaran memiliki motivasi yang cukup tinggi sebagaimana ditunjukkan tingkat partisipasi dalam bentuk kehadiran dan interaksi harmonis kelompok sasaran dalam setiap kegiatan pembelajaran. Oleh karena itu, proses pembelajaran perlu diarahkan terlebih dahulu pada pembentukan motivasi kelompok sasaran melalui mekanisme penyadaran yang berbasis pada masalah mereka sendiri pada permulaan kegiatan penguatan literasi budaya dilakukan. 


\section{PENUTUP}

\section{KESIMPULAN}

Tindakan penguatan kemampuan literasi budaya dilakukan dalam rangka membentuk kemampuan tersebut. Tindakan penguatan dalam bentuk pembelajaran. Pelaku seni-budaya harus memiliki kemampuan literasi budaya agar optimal dalam menjalankan peran melestarikan dan mentransformasikan kebudayaan dalam kehidupan bermasyarakat. Pelaksanaan tindakan mampu memberikan hasil belajar yang positif terhadap warga belajar yaitu kelompok sasaran memiliki kesadaran untuk melestarikan budaya, mampu memahami urgensi dan makna literasi budaya dan pengelolaan budaya berbasis masyarakat dalam rangka mengembangkan potensi budaya yang berkembang di wilayah masyarakat untuk pemberdayaan masyarakat.
Mendasarkan pada temuan di atas, untuk mengembangkan kemampuan literasi budaya yang lebih optimal bagi pelaku seni-budaya, maka diperlukan diperlukan suatu tindakan penguatan lain dalam bentuk pendidikan dan pelatihan yang dimaksudkan untuk memberikan kesempatan belajar kepada kelompok sasaran melalui (a) penyediaan substansi pembelajaran yang dapat membekali kelompok sasaran dengan sikap, keterampilan, dan pengetahuan literasi budaya yang aplikatif dan bermakna, (b) proses pembelajaran yang lebih dapat mengeksplorasi pengalaman dalam mengembangan seni budaya yang dapat menjadi sumber belajar, dan (c) menciptakan motivasi memotivasi warga belajar dalam memaknai hasil belajar dalam rangka mengembangkan diri dan lingkungannya.

\section{DAFTAR PUSTAKA}

Aminah, S., \& Prasetyo, I. (2018). Partisipasi masyarakat dalam pengembangan organisasi wahana kesejahteraan sosial berbasis masyarakat (WKSBM). JPPM (Jurnal Pendidikan dan Pemberdayaan Masyarakat), 5(1), 61-73. doi:https:// doi.org/10.21831/jppm.v5i1.17531

Arbarini, Mintarsih., Jutmini, Sri., Joyoatmojo, Soetarno., \& Sutarno, Sutarno. (2018). Effect of participatory learning model on functional literacy education. Jurnal of Nonformal Education, Vol 4 (1) (2018), 13-24. DOI: http://dx.doi.org/10.24914/ pnf.v4i1.13570

Hirsch, Jr. (1983). Cultural literacy. The American Scholar, Vol. 52, No. 2 (Spring 1983), pp.159169. Diakses dari https://www.jstor.org, tanggal 22 Mei 2019.

Fagerlind, Ingamer and Saha, J. Lawrence., (1983). Education and national development. New york: Pergason Press.

Foley, Giff. (2004). Dimensions of adult learning. Berkhire: Open University Press.

Gee, James P. (2015). Literacy and Education. New York: Routledge

Hermawan, Y., \& Suryono, Y. (2016). Partisipasi masyarakat dalam penyelenggaraan program-program pusat kegiatan belajar masyarakat Ngudi Kapinteran. JPPM (Jurnal Pendidikan dan Pemberdayaan Masyarakat), 3(1), 97-108. doi:https://doi.org/10.21831/jppm.v3i1.8111

Ife, Jim \& Tesoriero, Frank. (2008). Community devel- opment: alternatif pengembangan masyarakat di era globalisasi. Penerjemah Manulang, Dkk. Yogyakarta: Pustaka Pelajar.

Illeris, Knud. (2004). Three Dimensions of Learning. Florida: Krieger Publishing Company.

Kemdikbud. (2017). Panduan gerakan literasi nasional. Diakses dari http://gln.kemdikbud.go.id/glnsite/ wp-content/uploads/2017/08/panduan-gln.pdf tanggal 22 Mei 2019.

Knowless, M.S., Holton III, E. F., \& Swanson, R.A. (2005). The adult learner: The definitive classic in adult education andhuman resource development. Burlingtong: Elsevier.

Lind, Agneta. (2008). Literacy for all: Making a difference. Paris: The United Nations Educational, Scientific and Cultural Organization.

Mclntyre, A. (2007). Participatory action research (Vol. 52). Sage Publications.

Muarifuddin. (2017). Implementasi pembangunan Desa Wisata Batik Desa Babagan Kecamatan Lasem Kabupaten Rembang. Jurnal Pendidikan dan Pembangunan Masyarakat (JPPM), 4 (1), 2017, 51-70, DOI: http://dx.doi.org/10.21831/ jppm.v4i1.12713

Pai, Young. (1990). Cultural foundation of education. Columbus: Merrill Publishing Company.

Suárez-Orozco, Marcelo M. \& Qin-Hilliard, Desirée Baolian. (2004). Globalization culture and education in the new millennium. California: University of California Press. 
Penguatan Literasi Budaya...

Sumarno. (2009). Pembudayaan Literasi. Jakarta: Kemdiknas.

Tohani, Entoh., Wibawa, Lutfi., \& Dzajifah, E. R. (2017). Pengembangan model pendidikan sadar bercana berbasis modal sosial untuk mengembangkan resiliensi masyarakat rawan bencana. Laporan Penelitian Tidak Diterbitkan.
Yogyakarta: FIP UNY

UNESCO. (2006). Education for all: Literacy for life.

Paris: The United Nations Educational, Scientific and Cultural Organization

Widayati, T. (2006). Partisipasi perempuan dalam pengambilan keputusan di tingkat desa. Jurnal IImiah Visi, 1(1), Juni 2006, 57 - 63. https://doi. org/https://doi.org/10.21009/JIV.0101.7 